Prepublication copy: This article was published online in the International Journal of Entrepreneurial Behavior and Research on 22 October 2020.

See https://doi.org/10.1108/IJEBR-09-2019-0545 and will appear in an issue after 26(7) with page numbers.

\title{
Franchising microbusinesses: Coupling identity undoing and boundary objects
}

\author{
Colleen E. Mills \\ colleen.mills@,canterbury.ac.nz
}

Faith Jeremiah

contactfaith@gmail.com

University of Canterbury Business School, Christchurch, New Zealand

Purpose: This study presents an original empirically-based conceptual framework representing mobile microbusiness founders' experiences when converting to a franchise business model that links individual-level variables to a sociomaterial process.

Design/methodology/approach: An exploratory interpretive research design produced this framework using data from the enterprise development narratives of mobile franchisors' who had recently converted their mobile microbusinesses to a franchise business model.

Findings: The emergent framework proposes that franchisor's conversion experience involves substantial identity work prompted by an identity dilemma originating in a conflict between role expectations and franchising operational demands. This dilemma materializes during franchise document creation and requires some degree of 'identity undoing' to ensure business continuity. By acting as boundary-objects-in-use in the conversion process, the franchise documents provide a sociomaterial foundation for the business transition and the development of a viable franchisor identity.

Research limitations/implications: There is scant literature addressing the startup experiences of mobile microbusiness franchisors. The study was therefore exploratory, producing a substantive conceptual framework that will require further confirmatory studies. 
Practical implications: By proposing that conversion to a franchise business model is experienced as an identity transformation coupled to a sociomaterial process centred on system documentation, this original empirically-based conceptual framework not only addresses a gap in the individual-level literature on franchise development but provides a framework to direct new research and discussions between intending franchisors and their professional advisors about person-enterprise fit.

Originality: The conceptual framework is the first to address franchisors' experience of transitioning any type of microbusiness to a franchise business model.

Keywords: Franchising, Mobile microbusiness, Identity undoing, Boundary object, Sociomateriality

Article Classification: Research Paper

\section{Introduction}

The modern franchise business model has a long history (Dant et al., 2011; López-Fernández and López-Bayón, 2018; Pardo-del-Val et al., 2014) and continues to contribute significantly to the global economy (Dant et al., 2011; Gillis et al., 2018; Watson and Johnson, 2010). However, despite the research interest fuelled by the rising number of franchise units worldwide (Nijmeijer, Fabbricotti and Huijman., 2014) particularly in the United Kingdom and USA (Welsh, Alon and Falbe, 2006), and the strong franchisor-based literature (Dant, Grünhagen and Winsperger, 2011), very few of these studies have examined the personal transformation that accompanies a business owner's conversion from a conventional business model to a 'franchise system' (e.g., Kirby and Watson, 1999; Watson, 2008). The literature examining how franchisors adjust as their systems age (Hossain and Wang, 2008) is 
remarkably silent about the individual-level experience of converting a conventional business into a franchise system. Instead, the emphasis is more on post-startup management and strategy variables such as franchisor-franchisee relationships (e.g., Dada and Watson, 2012;Jang and Park, 2019; López-Bayón and López-Fernández, 2016; López-Fernández and López-Bayón, 2018; Watson and Johnson, 2010), ownership structure (e.g., Dant et al., 2008; Kaufmann and Eroglu, 1999), and network size (e.g., Kacker et al., 2016).

This empirical article addresses this gap in the literature. It begins by reviewing the literature on franchising, organizational transformation, and the three conceptual lenses used to interpret the study's findings and construct the emergent conceptual framework: self-identity (Mills and Pawson, 2006; Watson, 2009), identity undoing (Nicholson and Carroll, 2013) and boundary objects (Spee and Jarzabkowski, 2009; Star and Griesemer, 1989). Next, it describes the exploratory interpretive research approach, before presenting and discussing the findings and the conceptual framework produced by the inductive analysis. The final section discusses this framework and the study's contributions to the franchising literature and practice.

\section{Literature Review}

\section{The Nature of Franchising}

Retail franchising has become an important and rapidly growing component of economies worldwide with domestic franchising reaching saturation in many Western countries and escalating in emerging markets (Welsh, Alon and Falbe, 2006) as investors see emerging markets as a logical extension of their local operation (Hadjimarcou and Barnes, 1998). The franchise model is a commercial, contractual relationship between a business owner (franchisor) and other parties (franchisees) that allows an established business format to be replicated in new markets (Dant and Grünhagen, 2014; Jang and Park, 2019; Madanoglu and Castrogiovanni, 2018). Stanworth and Kirby (1993, p. 333) observe that this business model 
"offers a promising chemistry for combining the economies of scale enjoyed by the franchisor with the flexibility of the franchisee to exploit local market situations" (quoted in Kirby and Watson, 1999, p. 342). In doing so, the busines owner transitions into a new role as franchisor and builds a new type of operational relationship, that of the franchisor-franchisee (Hou, Hsu and $\mathrm{Wu}, 2009$ ).

In business format franchising, the most common franchise format, the franchisor offers one or more franchisees a complete business package (Kaufmann and Eroglu, 1999) that includes an original business format. This package typically includes a standardised operating system and a marketing campaign designed to raise brand awareness (Jang and Park, 2019). The franchisee is able to legally trade using the operating system and the company brand name in return for mutual financial gain (Blair and Lafontaine, 2005; Combs et al., 2004; Jang and Park, 2019). When working well, this hybrid governance approach (Evanschitzky et al., 2016), by exchanging different but complementary resources (Combs et al, 2004), produces mutual benefits (Combs and Ketchen, 2003; Jang and Park, 2019) that have a trickle-down effect on the growth and prosperity of the entire system. Studies showing how this effect is achieved have addressed ownership structure, business format design, contract design, behaviour of the franchisor and the franchisee and their interaction (López-Fernández and López-Bayón, 2018), and the age and size of the system and its units (Nijmeijer et al., 2014). We know that the original firm can expand more rapidly by adopting a franchising business model because the franchisor can harness financial input from franchisees while simultaneously benefitting from economies of scale. However, there are risks, particularly when franchisees are highly entrepreneurial (Evanschitzy et al., 2016; Jang and Park, 2019; Lanchimba et al., 2018) or unscrupulous (Hoy, 1994).

Encouraged by several special issues (e.g., Journal of Small Business Management vol. 50 issue 4, 2012) and the phenomenal growth of franchising in the USA and UK (Welsh, Alon 
and Fable, 2006), franchising has now gained a substantial literature (For reviews see Combs et al., 2004; Combs et al., 2011; Dant, Grünhagen and Winsperger, 2011; Elango and Fried, 1997; Nijmeijer et al.,2014; Welsh, Alon and Falbe, 2006; Wright and McAuley).

Significantly, these reviews show that the early franchising literature contained many franchisor-based studies (Dant, Grünhagen and Winsperger, 2011) as well as studies examining franchisor and franchisee skills and attitudes (Nijmeijer, 2014) but continues to pay scant attention to the business owner's personal experience as they become a franchisor, particularly when translating from an existing business to a franchise business model. This is despite speculation that perhaps a "franchise orientation" exists; an orientation that is an expression of certain types of personality characteristics or other individual-level differences in motivation" (Combes et al., 2011, p. 119) not unlike the "enterprise orientations" of entrepreneurs in the designer fashion sector described by Mills (2011). The franchise literature, however, has remained remarkably silent about the startup orientations and personal experiences of those converting an existing mobile microbusiness into a franchise operation despite such microbusinesses being a financially accessible form of business and potentially the simplest to franchise (Chow and Frazer, 2003).

\section{Organizational Transformation: From Conventional to Franchise Business}

Organisations are not static forms undergoing occasional episodic change. They are constantly emerging (Orlikowski, 1996; Tsoukas and Chia, 2002; Weick and Quinn, 1999). Floyd and Fenwick's (1999) five-stage franchise development model captures this constant emergence. The creation of a conventional business ('hatchling stage') progresses to the creation of the first franchise opportunity that runs alongside the conventional business configuration ('nestling stage'). When the first franchisee commences trading, this marks the beginning of the 'fledgling stage', while the 'adult stage' is marked by expansion of franchise units and typically includes establishing a head office that is primary concerned with strategy and 
managing the delicate franchisor-franchise relationship. In the 'post adult stage' the business expands internationally.

Not all franchise systems proceed through all stages or do so in the same way. Many never achieve adulthood (Floyd and Fenwick, 1999). For example, in the USA 50-85 percent of new franchise initiatives are estimated to fail (Nijmeijer et al., 2014). A planned organizational change often increases participants' stress levels (Dahl, 2011), which can interrupt on-going operations, impact on the desired outcome, and cause resistance to change (Whittle and Suhomlinova, 2010). Furthermore, it has been widely recognised that morphing from one role to another or adopting a new identity is neither a simple nor linear process (Hoang and Gimeno, 2010). It involves both progressive and retrogressive processes (Ambos and Birkinshaw, 2010). When converting to a franchise model, the business owner writes their new role into being as they document organizational practices and expectations (Kogut and Zander, 1996) to ensure both franchisor and franchisee have an explicit system to control their collaboration. It is therefore surprising that little attention has been paid to the process of producing franchising documents (Solis-Rodriguez and Gonzalez-Diaz, 2012).

In Fried and Elango's (1997) review of the franchising literature, the process of conversion is addressed only in terms of the reasons to franchise and the process of determining which business units should be franchised. The review reveals a dearth of articles examining conversion to a franchise model from an interpretive perspective.

Jambulingam and Nevin's (1999) study of entering a franchise contract from the perspective of the franchisor represents one of the few that examine franchise startup from this perspective. It finds the franchisor can achieve input control through their criteria for selecting franchisees and links these selection criteria to franchisors' desired outcomes. However, like so much of the franchising research, they seek to predict franchise performance and success without grappling with the finer individual-level details of the 
franchisor's personal experience (e.g., self-identity, life style expectations, relationship with the business). Similarly, Hossain and Wang (2008) use data from secondary sources to explore how the franchisors' cumulative experience, defined in terms of the franchise system size and franchise age, shapes the management of their contractual relationship with franchisees. This relative absence of research examining the fine nuances of the franchisor's lived-in experience from their point of view is more pronounced in some countries such as Australia where, until relatively recently, franchising research has been limited to case studies and census or survey-based scoping (Wright and McAuley, 2012) and concerned with more structural (e.g., franchise system evolution) and economic considerations.

\section{Establishing the First Franchise Opportunity}

The move to a franchise model constitutes "a fundamental change to the nature of the business" (Watson 2008, p.18) and personal relationships that sustain it. We know the process of planning, organising, recruiting and selecting appropriate franchisees to achieve this change is time consuming (Gillis et al, 2018; Jeremiah, 2012, 2016; Stanworth et al. 2001) and can present challenges of such magnitude that the franchising aspect of the business fails (Gillis et al., 2018; Hannan and Freeman, 1984; López-Fernández and López-Bayón, 2018; Madanoglu and Castrogiovanni, 2018).

The franchising literature acknowledges the significance of this first franchise startup phase, proposing that the first few years of franchising are crucial to the longevity of the franchise (Shane and Spell, 1998; Stanworth et al., 2004; Wadsworth and Cox, 2011; Watson, 2008). It also contains many studies of franchisors' attitudes and skills (See Nijmeijer et al., 2014) so it is puzzling that so little research addresses the business owner's personal experience as franchising commences. Within the literature that specifically addresses franchisors (See Frazer 2001; Kirby and Watson, 1999; Knight 1986; Stanworth et al. 2001; Watson, 2008) there is a paucity of studies examining the nascent franchisor's personal 
transition experience despite recognition that a franchised business is very different from a conventional one (Stanworth et al., 2004). This is consistent with Combs et al.'s (2004) observation that there is a "dearth of individual-level research" and their call for the "application of concepts and theories offered by social sciences that traditionally have not examined franchising" (Combs et al.'s, 2011, p.101). Our study responds to this call by focusing on mobile franchisors' accounts of their experiences as they convert to a franchising model. We chose mobile microbusiness conversion for two main reason. First, these businesses continue to be largely ignored in the literature despite mobile franchises growing in popularity (e.g., in Australia, Chow and Frazer, 2003) and, second, they are typically owned and operated by a single individual or a couple so the transition process is a very personal experience. In choosing to study the translation of microbusinesses to a franchising model we need to differentiate the businesses we studied from microfranchises in impoverished base-of-the pyramid (BOP) markets such as those found in under-developed countries (See Henriques and Nelson, 1997; Kistruck, Webb, Sutter and Ireland, 2011). 'Micro' in our study referred to the number of people required to run the business rather than the size of their financial investment or any associated intention to generate social benefits for those in underserved communities (Fairbourne, Gibson and Dyer, 2007). Businesses in our sample had more in common with family franchises as described by Chirico, Welsh, Ireland and Sieger (2020) who argue that a family firm franchise differs from a non-family one in terms of the strength of the franchisor-franchisee relationship and the amount of franchisee training provided.

\section{Changing Self-Identities}

Identity is a multifaceted and contested concept (Coupland and Brown, 2012) that is studied extensively from multiple perspectives (Brown, 2015). Self-identity, sometimes called personal or internal identity, is defined as "the character that the individual takes themselves to 
be" (Watson, 2009, p. 255) and is acknowledged as articulating with external social identities (Chasserio et al., 2014). It is constructed from an acknowledgment and acceptance of "who I am" and is shaped by self-characterisation, social and professional networks, sensemaking, and rapport with what one creates or does (Mills and Pawson, 2006; 2012). Such characterizations suggest that self-identity is constructed in concert with others, at least in part, through work practices (Jansson, 2013). Changes in these practices may produce resistance if the self is challenged in some way (Hoang and Gimeno, 2010) with the result that existing conceptions of the self can persist in times of change despite conflicting with required new identities.

Self-identity contributes to an individual's enterprise orientation (Mills, 2011), which plays a significant role in startup strategy and how this is experienced. It is surprising, then, that there are still very few studies that capture how self-identity evolves across the early stages of a new venture (Lundqvist et al., 2015). In terms of franchising, this means we know little about the liminal state that develops as the business owner's sense of self is reconfigured into that of a franchisor or the identity work, "the mutually constitutive processes whereby people strive to shape a coherent and distinctive notion of personal self-identity" (Watson, 2008, p. 129) which achieves this transition.

\section{Identity Undoing}

In their study of participants in a leadership development programme, Nicholson and Carroll (2013) encountered an absence of words such as "construction, acquire, build, maintain and protect" commonly employed in the literature when referring to identity. Instead they found opposites like "deconstruct, loss, letting go, shaken up and experiment" which they interpreted as signposts of 'identity undoing' (Nicholson and Carroll 2013, p.1230). Bjursell and Melin, (2011) encountered a process of identity undoing among women who become entrepreneurs in family businesses. The term identity undoing captures well the important process of clearing 
the way to establish a new sense of self through learning new roles and activities (Hannan and Freeman, 1984; Stanworth et al., 2001).

An exploratory review of papers published in the top six entrepreneurial academic journals (for rankings, see Hussain, 2011) revealed a dearth of literature on identity undoing, identity letting go, and identity disengagement although a growing literature on changes in work role and career change (Ibarra et al., 2010) is evident. Literature was located on loss and letting go (Day et al., 2009; Van Velsor and Draft, 2004), role abandonment (Hoang and Gimeno, 2011) and disembedding (Ibarra et al., 2010) and the stages involved in becoming entrepreneurial was found to touch the edges of the concept of identity undoing but no articles focusing on identity and the transition to franchisor were located. Hoang and Gimeno's conceptual study (2011) appears to be the only study directly addressing business founders' struggle to disengage from their old selves as they develop a new identity. This suggests that the significant inhibitors to adopting a new role are the degree of novelty in the new role and role conflict with other roles.

\section{The Role of Boundary Objects}

Star and Griesemer (1989), who formulated the concept of boundary objects, defined them as "flexible epistemic artefacts that inhabit several intersecting social worlds and satisfy the information requirements of each of them" (p. 393). They propose that boundary objects are sociomaterial ${ }^{1}$ tools that need to be sufficiently pliable to adjust to varied users' limitations, yet maintain a level of consistency that allows them to be recognised in different social worlds. These authors assert that strengthening and conserving a level of coherence across interconnecting worlds requires the creation and maintenance of appropriate boundary objects.

\footnotetext{
${ }^{1}$ The term sociomateriality is an increasing widely used term thatrefers to 'the constitutive entanglement of the social and the material in everyday organizational life' (Orlikowski, 2007, p. 1438).
} 
Not every artefact is a boundary object. Artefacts operate as boundary objects when they are meaningful and imbedded in the activities of users from a variety of domains, preserving different meanings for individuals from varied social settings (Levina and Vaast, 2005). They connect communities together and provide a communicative tool for articulating messages to varied users. Spee and Jarzabkowski (2009, p. 227) agree, observing that, "artefacts do not necessarily have 'proper' uses in practice", but rather may fulfil different purposes for different users. The franchise contract, for example, may serve differently purposes for the franchisor compared to their franchisees.

Levina and Vaast (2005) differentiate between boundary objects and boundary objectsin-use. Boundary objects-in-use are artefacts that not only have meaning but also provide different solutions across different groups workers while at the same time having a common identity across these groups (Spee and Jarzabkowski, 2009) which gives them their boundaryspanning capability.

Boundary objects perform a range of functions (Doolin and Mcleod, 2012) that can inhibit or enhance the transfer, translation, and articulation of knowledge across boundaries (Bechky, 2003). According to Carlile $(2002 ;$ 2004) there are three knowledge boundaries: syntactic, semantic, and pragmatic. When syntax is shared and relatively stable across a given boundary this enhances the likelihood of accurate communication between a sender and a receiver (Carlile, 2002). In contrast, working across the semantic boundary requires common meanings to exist between the parties concerned. Pragmatic boundaries are "the most socially and politically complex" (Spee and Jarzabkowski, 2009, p. 226) as these require shared interests to develop so knowledge is to be effectively transformed across the boundary. Boundary objects not only allow actors to develop their knowledge through learning, but also interpret and transform their knowledge into practices across boundaries in ways stabilised by the object's materiality (Carlile, 2002; Doolin and Mcleod, 2012). Thus, boundary objects 
establish a space that facilitates the on-going process by which knowledge is communicated, learned, translated, and transformed (Carlile, 2002; Doolin and Mcleod, 2012; Orlikowski, 2006) between individuals and the groups to which they belong.

While boundary objects have been addressed, in the information systems (e.g., Doolin and McLeod 2012) and strategy literatures (e.g., Barley et al., 2012; Leonardi 2015; Spee and Jarzabkowski, 2009), this concept has not gained traction in the franchising literature. This is surprising given the boundary spanning roles of documents (e.g., operation manual, franchise contract, disclosure document and franchise prospectus) which define franchise operations (Stanworth et al., 2001; Floyd and Fenwick, 1998).

\section{Research Questions}

The scant attention paid in the franchising literature to how microbusiness owners, particularly those with mobile businesses, experience the converting to a franchise model prompted us to ask research question one:

RQ1 How do mobile micro-business owners experience the conversion to a franchise model? And then, as the analysis progressed, we asked:

RQ2 What roles does franchise document development play in the nascent franchisor's experience?

\section{Methodology: A Narrative Inquiry}

A narrative is a spoken or written text that accounts for chronologically connected events (Czarniawska, 2004). While narrative can be traced to linguistics and literary criticism (Larty and Hamilton, 2011), the term 'narrative inquiry' was first used by Connelly and Clandinin (1990) in the educational field to bring order to "theoretical ideas about the nature of human life as lived to bear on educational experience" (p. 3). Subsequently, narrative inquiry has been 
used extensively in various ways across a wide range of fields including organisational studies (Boje, 1991; Brown et al., 2008; Czarniawski, 1997), community studies (Huber and Whelan, 2001), nursing (Barton, 2006), anthropology (Bateson, 1994), occupational therapy (Clandinin, 2007) and cross-cultural studies (Soin and Scheytt 2006). Surprisingly, narrative has only begun to feature in small business and entrepreneurship research relatively recently (Fletcher, 2007; Larty and Hamilton, 2011; Mills and Pawson, 2006; O'Connor, 2002; Rae, 2004), spurred on by prominent publications such as a 2007 special issue of Journal of Business Venturing, Hjorth and Steyaert's (2004) book Narrative and Discursive Approaches in Entrepreneurship, and Johansson's (2004) and Gartner's (2010) papers advocating for more narrative research in entrepreneurship.

We chose a narrative method to elicit rich accounts while preserving the chronology of startup events (O’Connor, 2002) and capturing the sense franchisors make of these (Reissner, 2005). The narratives revealed each franchisor's span of actions, decision making and sensemaking as well as the people and resources used to translate to a franchise model (Clandinin, 2007).

\section{Participant Selection}

We focused on mobile franchisors for three reasons. First, these increasingly visible microbusinesses attract little research attention. Second, they are typically owned and operated by a single individual or a couple so the transition process is a very personal experience and unlikely to have included any employees. Third, the small identifiable population of microbusiness entrepreneurs who have converted to mobile franchise operations spans many sectors, allowing a cross-sector sample to be constructed. 
Table 1: Participant Profiles

\begin{tabular}{|l|l|l|l|l|l|}
\hline & $\begin{array}{l}\text { Food } \\
\text { (Fred) }\end{array}$ & $\begin{array}{l}\text { Services } \\
\text { (Steven) }\end{array}$ & $\begin{array}{l}\text { Retail } \\
\text { (Rebekah) }\end{array}$ & $\begin{array}{l}\text { IT } \\
\text { (Ingrid) }\end{array}$ & $\begin{array}{l}\text { Transport } \\
\text { (Thomas) }\end{array}$ \\
\hline $\begin{array}{l}\text { Business exposure during } \\
\text { childhood }\end{array}$ & No & No & No & No & No \\
\hline Business partner & Yes & Yes & No & Yes & Yes \\
\hline Highest qualification & $\begin{array}{l}\text { Marketing } \\
\text { Diploma }\end{array}$ & $\begin{array}{l}\text { No tertiary } \\
\text { qualification }\end{array}$ & $\begin{array}{l}\text { Graduate } \\
\text { registered } \\
\text { nurse }\end{array}$ & $\begin{array}{l}\text { Bachelor of } \\
\text { Education }\end{array}$ & $\begin{array}{l}\text { No tertiary } \\
\text { qualification }\end{array}$ \\
\hline Previous profession & $\begin{array}{l}\text { Radio } \\
\text { executive }\end{array}$ & Baker & Nurse & Teacher & IT worker \\
\hline Previous business & $\begin{array}{l}\text { Yes: Inbound } \\
\text { tourism }\end{array}$ & $\begin{array}{l}\text { Yes: Pest } \\
\text { Control }\end{array}$ & No & No & No \\
\hline Age bracket & $50-59$ & 40-49 & $50-59$ & 40-49 & $30-39$ \\
\hline Male/female & Male & Male & Female & Female & Male \\
\hline Reason to start franchising & $\begin{array}{l}\text { Best fit with } \\
\text { cash business } \\
\text { model }\end{array}$ & $\begin{array}{l}\text { Seeking } \\
\text { more } \\
\text { committed } \\
\text { personnel }\end{array}$ & $\begin{array}{l}\text { Opportunities } \\
\text { to pass on } \\
\text { success }\end{array}$ & $\begin{array}{l}\text { Grow and } \\
\text { market brand } \\
\text { faster }\end{array}$ & $\begin{array}{l}\text { Produce } \\
\text { something } \\
\text { tangible for } \\
\text { investors }\end{array}$ \\
\hline $\begin{array}{l}\text { Time in business prior to } \\
\text { franchising }\end{array}$ & Four years & $\begin{array}{l}\text { Less than one } \\
\text { year }\end{array}$ & Four years & Three years & $\begin{array}{l}\text { Less than one } \\
\text { year }\end{array}$ \\
\hline Actively franchising & Yes & No & Yes & No & Yes \\
\hline
\end{tabular}

A sample of five would be considered a limitation in a quantitative study - judgement that has its origins in the positivist ideology (Boddy, 2016; Cavana et al., 2001; Denzen and Ryan, 2007). Today small-scale interview-based studies are increasingly popular, especially in the social sciences (Bryman, 2012; Cavana et al., 2001; Denzen and Ryan, 2007; Marshall et al., 2013) where the value qualitative studies with small sample sizes (Boddy, 2016; Bryman, 2012), is recognised, especially among those undertaking interpretive studies. Crouch and McKenzie (2006) propose that small samples $(\mathrm{N}<20)$ ensure "the researcher's close association with the respondents, and enhance[s] the validity of fine-grained, in-depth inquiry" (p.483) that produces a deep rather than general understanding of participants' realities.

\section{Data Collection and Analysis}

Semi-structured telephone interviews were used to collect the franchise startup narratives. These were transcribed and then read several times to appreciate the narrative in its totality 
before the detailed examination was conducted. Any ambiguity or lack of detail was addressed by follow-up emails. In Rae's (2004) study of the practical theories in entrepreneurs' stories, he "coded, compared and clustered" segments of narrative text, to identify not only the themes associated with episodes of learning, but also entrepreneurs' practical theories. Mirroring this process, our analysis sought to identify segments of the narratives that revealed the franchisor's 'lived transformational experience' and how they described and accounted for it. Themes embedded in these segments were coded using themes that were suggested by the text or which were consistent with concepts from the extant literature. Then a comparative analysis was conducted to identify patterns, disjunctions and paradoxes across the set of narratives.

This comparative analysis revealed the centrality of each participant's self-identity transformation and the salience of document creation in their franchise startup experience, so the data were explored further using these two conceptual lenses and led to a focus on identity undoing and boundary objects. Extant concepts from the literature such as these were only incorporated into the emerging findings when suggested by the analysis. This method is consistent with Tracy's (2013, pp. 21-27) description of qualitative research using the inductive method and ensures that the researcher does not pre-empt their analysis using a prescriptive conceptual framework grounded in the extant literature.

\section{Findings and Discussion}

The first stage of analysis confirmed that the microbusiness owners experienced an identity transformation as they assumed the mantle of franchisor. Significantly implicated in each owner's transformation was the process of documenting (i.e., materializing) their business system so it could be replicated. The emergent conceptual framework that captures the participants' transition process is presented at the end of this section. 


\section{Identity Undoing}

As noted earlier, self-identity involves self-characterisation that answers the question 'who am I?' (Mills and Pawson, 2006; 2012). The resulting sense of self integrates the individual's activities, roles, and social connections so it is not surprising, that when confronted with change, particularly when this involves a role change or new routines or activities, this selfidentity is challenged (Hoang and Gimeno, 2010).

Each business owner reported being confronted with circumstances that required making unforeseen changes that led to new answers to the questions 'who am I?' and 'what have I created?' These changes challenged prior self-perceptions and triggered sudden reconsideration of the desirability of a franchise business development and the disruption of established self-identities. No longer were these business owners simply specialists engaged operationally in their particular industries, they were becoming franchisors and shifting their main roles and identities accordingly. Steven, the service franchisor, recounted this surprise as he realized he needed to reconcile existing and emerging business activities.

Well, I had my own established business to run and ..., then I had a franchising business as well and I guess my whole business sort of changed - it wasn't just about running my core business anymore - suddenly I had franchisees as well.

Like the others, he reported having to actively disengage from his old business identity - a process that is captured by the concept of 'identity undoing' (Nicholson and Carroll, 2013) - before being able to fully embrace the franchisor identity. Each franchisor reported noticing that their identity as "sole operator" and business owner had to unravel to provide room for the emerging franchisor identity (e.g. a franchisor providing franchisee support). Below, Thomas approaches this accommodation process in terms of company brand.

You know, you've built up your brand, you've built up your model, you've got to be very careful about what changes you make to it and what those impacts might be. 
Identity undoing or unravelling is captured by the notion of 'shaking up', which represents the "experience of having one's identity unsettled, disrupted and agitated" (Nicholson and Carroll, 2013 p. 1233). Hoang and Gimeno (2011) suggest that the conflict between two competing identities often arises "due to the challenges associated with assuming a new role while holding on to other potentially competing role identities that a person views as self-defining" (p. 43). The following excerpts illustrate how franchisors perceived transitioning to a franchise system negatively because it created conflict with their original business concept. Addressing this negativity formed part of the process of disengaging from the original owner-operator self-identity and letting go:

We found that we were turning into a company that ran franchises rather than a really good computer support company (Ingrid).

I viewed it as dangerous and not in line with what the original business plan was. In fact, I saw having a franchise as dangerous because it created a barrier as suddenly we were not just running what we were there to do. It took a bit away from our core business as well (Thomas).

Every franchisor reported being confronted in a very tangible way with some level of identity undoing either as a company or as an individual business operator when it came time to prepare the franchise documentation. This undoing happened in tandem with a process of re-identification as new roles became clear and were incorporated into an emerging business identity that aligned to franchising.

\section{Materializing the Emerging Identity}

Producing operation manuals, disclosure documents and franchise agreements required each franchisor to rethink how they operated their business, from the general routines down to the minute steps they performed within these to deliver their service or create a product. As they decided which aspects they wanted franchisees to replicate and which they would discard, the 
franchisor identity emerged. The IT franchisor reported engaging in a cognitive renegotiation as she created her franchise documents that saw her questioning what she wanted for herself as a business person and how she could incorporate this into the new franchising model she was documenting.

So, the first step that we took was to approach a lawyer to get an agreement sorted out and of course, through that, through sort of, talking to a lawyer, we had to work out what our model was going to be and how we were going to make money off it. And so, we sort of looked at it ourselves and worked out what we wanted and how we wanted it to work with the franchising side of things (Ingrid).

In contrast, Steven characterised the process as a merger or hybridization rather than a process of creating something new; as a matter of taking the lucrative aspects of his core business operation and combining these with the franchising concept. He expressed this when he stated, "I guess it had to be two business models in one really".

Externally provided frameworks shaped Fred, the food franchisor's startup experience. He narrated how materializing his mobile franchise business in text involved moulding and reshaping segments of information and modifying templates provided by advisors to accommodate this information. This process of choosing which aspects would be incorporated in these texts and which were left out became central to re-identifying himself with his business. His new identity thus materialised in a fashion that was distributed across externally provided frames (embodied in the templates) and his personal sense of what was required and sustainable. The following interview excerpts capture this process:

I mean, there are franchise agreement templates, but they need to be massaged and changed and sorted so that they match your particular business and the franchising side of things. ... It's about moulding aspects that are most suitable, really. So, the way you 
did things before franchising needs to be adapted too and all disclosed in the manual (Fred).

This document production process gave Fred a sense of agency and enabled him to reposition himself in his newly franchised business with a positive identity. His perception of himself and his business clearly changed. He likened his relationship to the new business to that of a parent and presented his self-identity as a family man, one with new responsibilities as a guardian of the offspring (franchisees) of the original business.

... you know, it was still the parent business but it just had many children spread around and our role was to watch over the children really. Yeah, I guess it's like that. You know, you go from being a single person to having a family! (Fred)

Thomas narrated his document development as something to get through, a hurdle that needed to be navigated, in order to reap benefits on the other side and accept the emerging franchisor identity as one of these benefits:

... that's the job of the franchisor, isn't it, to cope with the change of your business by somehow fitting this new franchising concept to your core business.... my view is that franchising is a great way once you have got everything in place, all the process locked down first .... (Thomas).

Rebekah spoke similarly but saw the benefits included acquiring an identity with associated new responsibilities that she likened to a partnership:

Once I franchised, I looked at my business as more of a partnership, when you got a partnership you're got a series of obligations I suppose. (Rebekah).

In the nascent franchisors' accounts of how they materialized their business system in the franchise documentation they variously described their new business identity as parent, family man, guardian, delegator, mentor and partner. These self-denotations suggest they were anticipating a varied array of business relationships with franchisees, each with inherently 
unique patterns of power and control. Much has been written about these relationships (see Nijmeijer et al., 2014).

Each franchisor's transformation went beyond developing new relationships. The following excerpts reveal how they had experienced a concomitant transformation in their sense of self that was coupled to the franchise startup process. These data suggest self-identity and organisational identity are simultaneously imbricated and mutually constitutive, something that is to be expected in microbusinesses like the mobile firms in this study where the owneroperator and possibly their spouse are typically the only people in the business.

I think franchising does have a direct effect on you as a person - I mean I've changednot the same person that went into this. But I think it's for the better, I do. (Fred)

People say I changed. I see it too. I have gone through a whole lot-learned a lot ... this experience has changed me, yeah. (Steven)

I'm no longer the same. I like the new me ha-ha-ha. I'm an organiser and project manager, an adviser and all these new roles now. I'm a much busier person. (Rebekah) Franchising has change me to a point, I think. I'm a different person now. I've definitely become more assertive and yeah, well I've changed -I'm a strong person now and firmer too. Well, you have to be. (Ingrid)

...well 'course I've changed. You go through this massive sort-of transformation of your business and so that affects you, you know. (Thomas)

\section{Franchise Texts as Boundary Objects}

Not only did producing franchise documents materialise the role transformation and important aspects of self-identity for the nascent franchisors, the documents served as boundary objects - artefacts specifically designed to be flexible and utilised by a variety of intersecting stakeholders for different reasons (Star and Griesemer, 1989). The operating document illustrates this boundary spanning function well. It provided a franchisee with the information 
necessary to replicate the original business, but also gave the franchisor control over the operation of each franchise unit. Fred, the food franchisor, likened it to 'a recipe'. Steven and Thomas found that this recipe, when perfected, made starting subsequent franchise units very efficient.

Somebody has to be able to take that manual, read it and basically use it like a recipe. Follow the recipe and be able to operate the franchise (Fred).

Producing documents that could operate successfully as boundary objects brought a strong communication focus to the franchise development process. Each nascent franchisor reported having to consider a range of audiences (e.g., lawyers and financiers) in addition to prospective franchisees to ensure that each document's boundary spanning purpose could be realised. Ingrid and Rebekah's comments capture the challenging nature of materialising the business operation for different audiences:

Well, it is very challenging putting together, aah [sic], the disclosure document and the operations manual because you cannot forget anything and once it is written down it is set in stone. So, I had to be really, really careful with that [...]. You realise that a lot of people read over and use these documents, for lots of different reasons. (Ingrid). It was very hard writing the manual for the franchise... I looked at what was the best for our business, and what would be the best for the franchise people and other interested people out there, you know (Rebekah).

Such comments are consistent with Star and Grismer's (1989) claim that the creation and maintenance of boundary objects play a pivotal role in creating and preserving consistency across a variety of parties. Consistency is certainly a primary consideration in a franchise system.

Carlie $(2002 ; 2004)$ suggests that boundary objects have utility, not only because of their legitimate power to communicate, but also because they enable those who engage with them 
to solve social conflict while negotiating and transforming their identities. However, the findings in this study reveal it was not a social conflict the franchisors were grappling with. Instead, it was a self-conflict that was resolved through the process of evaluating how the business was fundamentally run and marrying this to the franchise concept through documenting company practices and stakeholder relationships. This became the key to the emerging franchisor successfully 're-identifying' him or herself with their new business and is consistent with Star and Griesemer's (1989) suggestion that not only do boundary objects "act as anchors or bridges" (p. 414), they can overcome rather than reinforce boundaries and facilitate conflict resolution, particularly when change and innovation are required. It is not surprising then that the franchisors' interpretations of their document creation experiences revealed that it was intimately involved in ensuring a positive franchisor with a comfortable self-identity emerged, alongside the production of a replicable operating model.

\section{Professional Input and the Franchisor's Emerging Identity}

Professionals such as lawyers were important when documenting the new business as these relationship defining documents (Stanworth et al., 2004) are technically complex and must be legally binding. In this study, professional input produced multi-vocal franchising texts that constituted a significant social interface where the franchisors' identities were socially constructed. The franchisors in this study were sensitive to this intertextuality, recognising that the professionals' views became coupled to their own. For example, one stated: “... basically, the franchise agreement was from the lawyer" and spoke of the fresh perspective such professionals brought to her business development process and how their "ideas and values" influenced her emerging business design and sense of who she was becoming and what she was doing. 
[...] obviously the lawyer made sure that all the paperwork was tied up tight and the mentor just sort of, threw in some ideas and values. 'Have you thought about doing it this way?' 'Are you sure that is going to work?' (Ingrid).

Overall, the narrative analysis revealed that first franchise startup was experienced as a strongly collaborative affair with professionals being variously described as "a sounding board' and 'identity protector'. This is not surprising. Scholars have repeatedly highlighted the importance of lawyers, in particular, in the protection of intellectual property and business identity (e.g., Floyd and Fenwick, 1999; Watson et al., 2005). As Steven observed, the lawyers showed them "how to write a franchise document that was actually going to have some teeth if there were any issues."

Oswick and Robertson (2009) claim, "boundary objects have been presented in the extant literature as playing a pivotal role in initiating and facilitating change" (p. 179). This study's findings are consistent with this claim. In fact, the process of creating these boundary objects facilitated business transformation by creating a space for the franchisors to recreate their businesses and construct and communicate their new franchisor identity as they co-authored the various documents with the professionals they consulted.

\section{The Emergent Conceptual Framework}

Figure 1 presents the conceptual framework that integrates the findings for each theme in this section to represent the owner-operator's experience of converting to a franchise model. 


\section{Figure 1. The Emergent Conceptual Model}

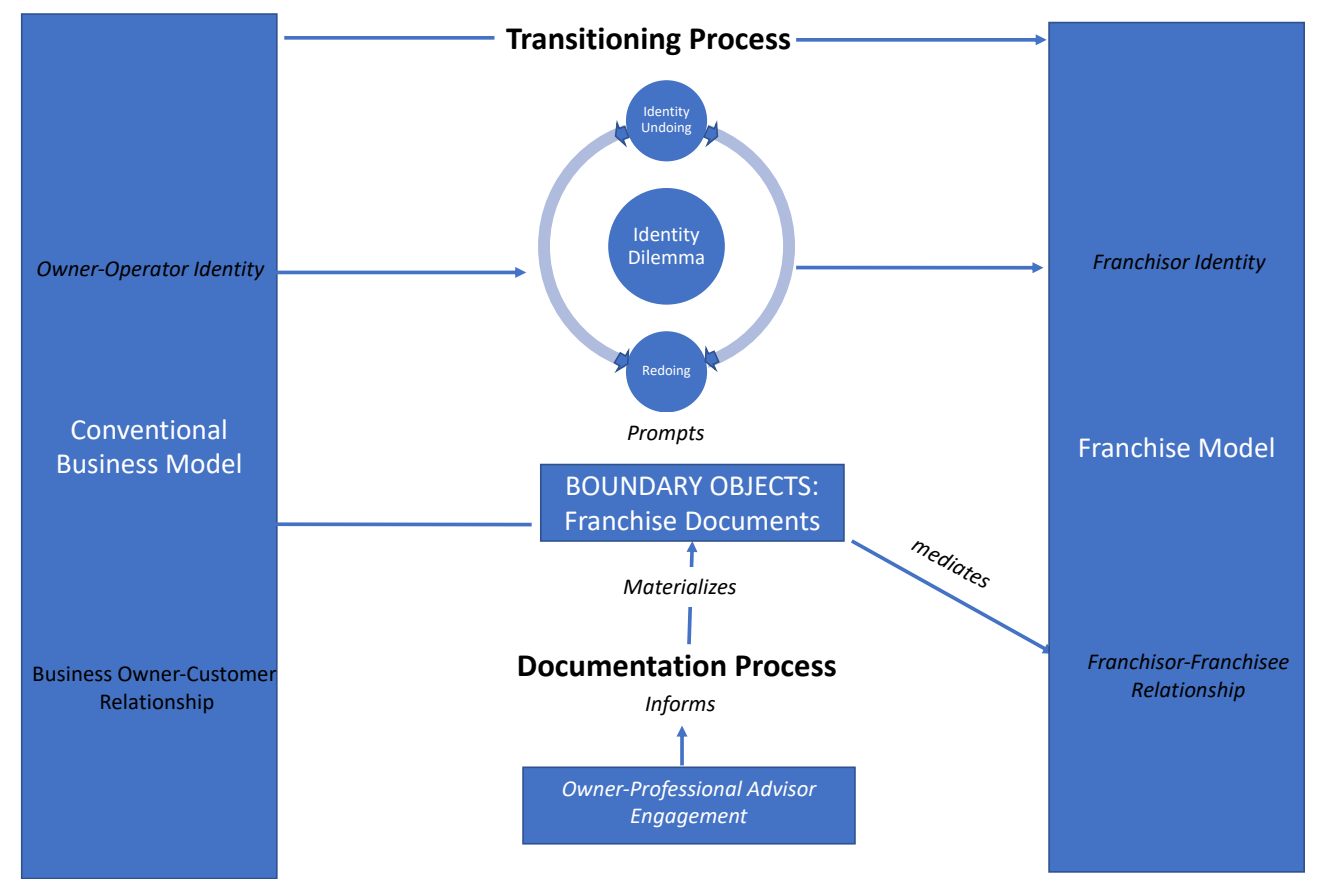

\section{Implications for Practice}

This study of franchisors' startup narratives responds to Fried and Elango's (1997) suggestion that more fine-grained research on franchising is needed to "capture the complexity and subtlety of actual business practice" (p. 77). Our in-depth analysis of five startup narratives sheds light on the previously under-explored experience of becoming a franchisor from the business owner's perspective, using the concepts of self-identity, identity undoing and boundary objects. In doing so, it contributes a new conceptual framework (Figure 1) that suggests franchise documents are a significant element in the identity undoing (Nicolson and Carroll, 2013) that is necessary for a successful transition from business owner/operator of a conventional business to the franchisor in a franchise system.

Figure 1 suggests that the process of creating the texts necessary to define a franchise operating system moderates the degree to which a nascent franchisor accepts their new franchisor identity or experiences its emergence as a dilemma. These documents do this by 
providing a space for the franchisor to undo their existing identity and construct a new sense of 'who they are' in collaboration with professional advisors.

Practically, the framework offers a tool for advisors to focus prospective franchisors' attention on the challenges that converting to a franchising model pose to their relationship with their business and how resolving these challenges can affect their self-identity. By helping microbusiness owners to appreciate that converting to franchising has very personal consequences, professional advisors could help them take a more self-reflective approach to business development process. They could also prevent some microbusiness owners from investing valuable time and money transforming their businesses when their enterprise orientations (Mills, 2011) simply do not fit well with the franchise business model.

\section{Implications for Theory}

In addition to being a study that our literature review suggests is the first to examine the transition to franchising from the perspectives of mobile business founders, this study is also the first to apply the concept of identity undoing (Nicholson and Carroll, 2013) to the identity work undertaken by business owners transitioning to a franchising model. In so doing, it responds to calls to apply more social science concepts and theories to the study of franchising (Combs et al.'s, 2011). Furthermore, it breaks new ground by providing evidence of the influence of franchise documentation on identity undoing. By addressing mobile microbusiness start-ups where the founder is the primary person working in the business, it was able to clearly demonstrate how this documentation initiates the self-identity changes required of the business founder. By proposing the franchising texts act as sociomaterial boundary objects that mediate not only the emergence of the franchise system's but also the franchisor's identity, the framework captures how such artefacts act as boundary-objects-in-use (Levina and Vaast, 2005), defining several important interfaces pivotal to translating an existing business into a franchise system. If this conceptual framework is confirmed by further studies, it will 
contribute a new theory that couples individual-level experience to a sociomaterial process at the heart of franchise system development.

\section{Conclusion}

Although this study was exploratory in nature and based upon a small number of cases, the indepth analysis made possible by a small set of rich narratives (Crouch and McKenzie, 2006). gave rise to a framework that offers valuable individual-level insights for scholars, intending franchisors and the professionals who provide them with information. Not only does it capture how franchise document development provides a meaningful space for distributed social action that propels the nascent franchisor towards a new identity, it demonstrates how this process can be accompanied by an identity dilemma (Jeremiah, 2016) that has its genesis at the interface between conflicting role expectations and the processual demands associated with assuming the mantle of franchisor. Most significantly, by proposing that some degree of identity undoing' (Nicholson and Carroll, 2013) is necessary to produce an identity that supports business continuation, the study focuses attention on the importance of achieving a personenterprise fit (Mills and Pawson, 2006).

Overall, the study's contributions are four-fold. First, it addresses a significant gap in the franchising literature: the paucity of studies addressing startup, the most critical stage in franchise system development (Shane and Spell, 1998). Second, it does this by contributing a conceptual framework to the scant literature on micro-business franchising that couples the creation of franchise documents, which act as boundary-objects-in-use, to the process of identity undoing that is necessary to resolve the business owner-operators' identity dilemma in favour of a functional franchisor identity. Third, by integrating the concepts of self-identity, identity undoing, and boundary objects to capture the experience of first-time franchisors as they assume the franchisor mantle it responds to calls for a more individual-level perspective in franchise studies (e.g., Combes et al., 2011). Fourth, by proposing franchise development 
presents the emerging franchisor with a significant identity dilemma that is both revealed, and potentially resolved, in the process of materializing their franchise business in conjunction with their professional advisors in their franchise documents, the study introduces the notion of sociomateriality into the franchising literature. We accept that the small number of mobile franchisors studied restricts the wider applicability of our conceptual framework but we hope others will be motivated by the insights it has provided to test its wider applicability and apply a sociomaterial lens (Jarzabkowshi and Pinch, 2013) to other aspects of enterprise development.

The study addresses a significant gap in the franchising literature - the paucity of studies addressing startup - by developing a conceptual framework that couples the creation of franchise documents, which act as boundary-objects-in-use (Levina and Vaast, 2005), to the process of identity. By integrating the concepts of self-identity (Mills and Pawson, 2006; Watson, 2009), identity undoing (Nicholson and Carroll, 2013), and boundary objects (Spee and Jarzabkowski, 2009; Star and Griesemer, 1989) to capture the experience of first-time franchisors it responds to calls for a more individual-level perspective in franchise studies. and introduces the notion of sociomateriality (Jarzabkowski and Pinch, 2013) into the franchising literature. It also links the microbusiness research to franchising and the process of transitioning to a franchise model.

\section{References}

Ambos, T.C. and Birkinshaw, J. (2010). "How do New Ventures Evolve? An Inductive Study of Archetype Changes in Science-Based Ventures," Organization Science, Vol. 21 No. 6, pp. 1125-1140. 
Barley, W.C., Leonardi, P.M. and Bailey, D.E. (2012). "Engineering Objects for Collaboration: Strategies of Ambiguity and Clarity at Knowledge Boundaries," Human Communication Research, Vol. 38 No. 4, pp. 280-308.

Barton, S.S. (2006). Spirit Winds: A Narrative Inquiry into the Aboriginal Stories of Diabetes. Published thesis, University of Alberta, Canada. ISBN: 0-494-13934-X

Bateson, M. C. (1994). Peripheral Visions: Learning Along the Way. New York: HarperCollins Publishers.

Bechky, B. (2003). “Object Lessons: Workplace Artifacts as Representations of Occupational Jurisdiction," American Journal of Sociology, Vol. 109 No. 3, pp. 720-752.

Bjursell, C. and Melin, L. (2011). "Proactive and Reactive Plots: Narratives in Entrepreneurial Identity Construction", International Journal of Gender and Entrepreneurship, Vol. 3 No. 3, pp. 218-235.

Blair, R.D. and Lafontaine, F. (2005). The Economics of Franchising. Cambridge: Cambridge University Press.

Boddy, C.R. (2016). “Sample Size for Qualitative Research”, Qualitative Market Research, Vol. 19 No. 1, pp. 426-432.

Boje, D.M. (1991). “The Storytelling Organization: A Study of Story Performance in an OfficeSupply Firm,” Administrative Science Quarterly, Vol. 36 No. 1, pp. 106-126.

Brown, A.D. (2015). “Identities and Identity Work in Organizations," International Journal of Management Reviews, Vol. 1 No. 1, pp. 20-40.

Brown, A.D., Stacey, P. and Nandhakumar, J. (2008). "Making Sense of Sensemaking Narratives," Human Relations, Vol. 61 No. 8, pp. 1035-1062.

Bryman, A. (2012). Social Research Methods. Oxford University Press, Oxford.

Cavana, R.Y., Sekaran, U. and Delahaye, B. L. (2001). Applied Business Research: Qualitative and Quantitative Methods, Wiley, Australia 
Carlile, P.R. (2002). “A Pragmatic View of Knowledge and Boundaries: Boundary Objects in New Product Development," Organization Science, Vol. 13 No. 4, pp. 442-455.

Carlile, P.R. (2004). “Transferring, Translating and Transforming: An Integrative Framework for Managing Knowledge Across Boundaries,” Organization Science, Vol. 15 No. 5, pp. $555-568$.

Chasserio, S., Pailot, P. and Poroli, C. (2014). "When Entrepreneurial Identity Meets Multiple Social Identities: Interplays and Identity Work of Women Entrepreneurs," International Journal of Entrepreneurial Behavior and Research, Vol. 20 No. 2, pp. 128-154.

Chirico, F., Welsh, D.H.B., Ireland, R D. and Sieger, P. (2020). "Family Versus Non-Family Firm Franchisors: Behavioural and Performance Differences”, Journal of Management Studies, First published online 10 February 2020. https://doi-org.ezproxy.canterbury.ac.nz/10.1111/joms.12567

Chow, L. and Frazer, L. (2003), "Servicing Customers Directly", European Journal of Marketing, Vol. 37 No 3/4, pp. 594-613.

Clandinin, D.J. (2007). Handbook of Narrative Inquiry: Mapping a Methodology, Sage Publications, Thousand Oaks, California.

Connelly, F.M. and Clandinin, D.J. (1990). "Stories of Experience and Narrative Inquiry," Educational Researcher, Vol. 19 No. 5, pp. 2-14.

Combs, J.G. and Ketchen (2003). "Why do firms use franchising as an entrepreneurial strategy? A meta-analysis", Journal of Management, Vol. 29, pp. 443-465.

Combs, J.G., Ketchen, D.J., Shook, C.L. and Short, J. C. (2011). "Antecedents and Consequences of Franchising: Past Accomplishments and Future Challenges," Journal of Management, Vol 37 No 1, pp. 99-126.

Combs, J.G., Michael, S.C. and Castrogiovanni, G.J. (2004). Franchising: A Review and Avenues to Greater Theoretical Diversity," Journal of Management, Vol. 30 No 2, pp. 
907-931.

Coupland, C. and Brown, A.D. (2012). "Identities in Action: Processes and Outcomes," Scandinavian Journal of Management, Vol. 28, No. 5, pp. 1-4.

Crouch, M. and McKenzie, H. (2006). "The Logic of Small Samples in Interview-Based Qualitative Research”, Social Science Information, Vol. 45 No. 4, pp. 483-499

Czarniawska, B. (1997). Narrating the Organization: Dramas of Institutional Identity, University of Chicago Press, Chicago

Czarniawska, B. (2004). Narratives in Social Science Research, Sage, London.

Dada, O. and Watson, A. (2012). "The Effects of Entrepreneurial Orientation the Franchise Relationship”, International Small Business Journal, Vol. 31 No. 8, pp. 955-977.

Dahl, M.S. (2011). “Organizational Change and Employee Stress,” Management Science, Vol. 57 No. 2, pp. 240-256.

Dant, R.P. and Grünhagen, M. (2014). "International Franchising Research: Some Thoughts on the What, Where, When and How", Journal of Marketing Channels, Vol. 21, pp. 124132.

Dant, R.P., Grünhagen, M. and Windsperger, J. (2011). "Franchising Research Frontiers for the Twenty-First Century," Journal of Retailing, Vol. 87 No. 3, pp. 253-268.

Dant, R.P., Perrigot, R. and Cliquet, G. (2008). "A Cross-Cultural Comparison of the Plural Form in Franchise Networks: USA, France and Brazil," Journal of Small Business Management, Vol 4 No. 2, pp. 286-311.

Day, D.V., Harrison, M.M. and Halpin S.M. (2009). An Integrative Approach to Leader Development: Connecting Adult Development, Identity, and Expertise, Routledge, New York. 
Denzin, N.K. and Ryan, K.E. (2007). “Qualitative methodology (including focus groups).” In W. Outhwaite and S.P. Turner (Eds.) The Sage Handbook of Social Science Methodology ( pp. 578-594). Sage.

Doolin, B. and Mcleod, L. (2012). "Sociomateriality and Boundary Objects in Information Systems Development”, European Journal of Information Systems, Vol. 21 No. 5, pp. $570-586$.

Elango, B. and Fried, V.H. (1997). "Franchising Research: A Literature Review and Synthesis", Journal of Small Business Management, Vol. 35 No. 3, pp. 68-81.

Evanschitzky, H., Caemmerer, B. and Backhaus, C. (2016). "The Franchise Dilemma: Entrepreneurial Characteristics, Relational Contracting, and Opportunism in Hybrid Governance,” Journal of Small Business Management, Vol. 54 No. 1, pp. 279-298.

Fairbourne, J., Gibson, S.W. and Dyer, W.G. (Eds.). (2007). Microfranchising: Creating Wealth at the Bottom of the Pyramid. Northampton, MA: Edward Elgar.

Fletcher, D. (2007). “'Toy Story”: The Narrative World of Entrepreneurship and the Creation of Interpretive Communities," Journal of Business Venturing, Vol. 20 No. 5, pp. 649672.

Flint-Hartle, S. and Weaven S. (2010). Franchising New Zealand Report 2010, Massey University and Griffith University, Auckland and Brisbane

Floyd, C. and Fenwick. G. (1999). "Towards a Model of Franchise System Development," International Small Business Journal, Vol. 17 No. 4, pp. 32-48.

Frazer, L., (2001). "Why Franchisors Discontinue Franchising But Continue Operating”, International Small Business Journal, Vol 19. No. 3, pp. 29-38.

Gartner, W.B. (2010). “A New Path to the Waterfall: A Narrative on a Use of Entrepreneurial Narrative,” International Small Business Journal, Vol. 28 No. 1, pp. 6-19. 
Gillis, W.E., Combs, J.G. and Yin, X. (2018), "Franchise Management Capabilities and Franchisor Performance Under Alternative Franchise Ownership Strategies”, Journal of Business Venturing, Vol. 50 No. 4, pp. 677-695.

Hannan, M. and Freeman, J. (1984). "Structural Inertia and Organisational Change," American Sociological Review, Vol. 49 No. 3, pp. 481-501.

Hadjimarcou, J. and Barnes, J. W. (1998). "Case Study: Strategic Alliances in International Franchising - The Entry of Silver Streak Restaurant Corporation Into Mexico,” Journal of Consumer Marketing, Vol. 15 No 6, pp. 598-607.

Henriques, M. and Nelson, R.E. (1997). "Using Franchises to Promote Small Enterprise Development", Small Enterprise Development, Vol. 8, pp. 23-31.

Hjorth, D. and Steyaert, C. (2004). Narrative and Discursive Approaches in Entrepreneurship, Edward Elgar, Cheltenham.

Hoang, H. and Gimeno, J. (2010). "Becoming a Founder: How Founder Role Identity Affects Entrepreneurial Transitions and Persistence in Founding," Journal of Business Venturing, Vol. 25 No. 1, pp. 41-53.

Hou, S-T., Hsu, M-Y. and, Wu., S-H. (2009). "Psychological Ownership and Franchise Growth: An Empirical Study of Taiwanese Taxi Drivers," International Journal of Entrepreneurial Behavior and Research, Vol. 15 No. 5, pp. 415-435.

Hossain, T. and Wang, S. (2008). "Franchisor's Cumulative Franchising Experience and its Impact on Franchising Management Strategies," Journal of Marketing Channels, Vol. 15 No. 1, pp. 43-69.

Hoy, F. (1994). "The Dark Side of franchising”, International Small Business Journal, Vol. 12 No. 2, pp. 26-38.

Huber, J. and Whelan K.K. (2001). "Beyond the Still Pond: Community as Growing Edges," Reflective Practice, Vol. 2 No. 2, pp. 221-236. 
Hussain, S. (2011). "Food for Thought on the ABS Academic Journal Quality Guide," Accounting Education, Vol. 20 No. 6, pp. 545-555.

Ibarra, H., Snook, S. and Guillen-Ramo, L. (2010). “Identity-Based Leader Development,” in Nohria, N. and Khurana, R., (Eds.), Handbook of Leadership Theory and Practice, Harvard University Press, Cambridge, MA, pp. 657-678.

Jarzabkowski, P. and Pinch, T. (2013). "Sociomateriality is 'the New Black': Accomplishing Repurposing, Reinscripting and Repairing in Context," Management, Vol. 16 No.5, pp. $579-592$.

Jambulingam, T. and Nevin, J.R. (1999). "Influence of Franchisee Selection Criteria on Outcomes Desired by the Franchisor," Journal of Business Venturing, Vol. 14 No. 4, pp. 363-395.

Jansson, N. (2013). “Organizational Change as Practice: A Critical Analysis," Journal of Organizational Change Management, Vol. 26 No 6, pp. 1003-1019.

Jeremiah, F. (2012). “The Start-Up Experience of Mobile Franchisors”. Unpublished Bachelor of Commerce Honours Dissertation: University of Canterbury.

Jeremiah, F. (2016). “Franchisors' Self-identity and Self-enactment During Franchise Start-up and its contribution to Franchising”. PhD Dissertation, University of Canterbury.

Johansson, A.W. (2004). “Narrating the Entrepreneur,” International Small Business Journal, Vol 22 No. 3, pp. 273-293.

Kacker, M., Dant, R.P., Emerson, J. and Coughlan A.T. (2016). "How Form Strategies Impact Size of Partner-Based Retail Networks: Evidence from Franchising," Journal of Small Business Management, Vol. 54 No. 2, pp. 506-531.

Kaufmann, P. and Eroglu, S. (1999). "Standardisation and Adaptation in Business Format Franchising," Journal of Business Venturing, Vol 14 No. 1, pp. 69-85. 
Kirby, D. and Watson. A. (1999). "Franchising as a Small Business Development Strategy: A Qualitative Study of Operational and 'Failed' Franchisors in the UK,' Journal of Small Business and Enterprise Development, Vol. 6 No. 4, pp. 341-349.

Kistruck, G.M., Webb, J.W., Sutter, J, and Ireland, R.D. (2011). "Microfranchising in Baseof-the-Pyramid Markets: Institutional Challenges and Adaptations to the Franchise Model", Entrepreneurship Theory and Practice, Vol. 35 No. 3, pp. 503-531.

Kogut, B. and Zander, U. (1996). "What Firms do? Coordination, Identity, and Learning," Organization Science, Vol. 7 No. 5, pp. 502-518.

Knight, R.M. (1986). Franchising from the franchisor and franchisee points of view. Journal of Small Business Management, Vol. 24, pp. 8-15.

Lanchimba, C., Windsperger, J. and Fadairo, M. (2018), "Entrepreneurial orientation, risk and incentives: The case of franchising”, Small Business Economics, Vol. 50 No. 1, pp. 163 180.

Larty, J. and Hamilton, E. (2011). "Structural Approaches to Narrative Analysis in Entrepreneurship Research: Exemplars from Two Researchers,” International Small Business Journal, Vol. 29 No: 3, pp. 220-237.

Leonardi, P.M. (2015). "Materializing Strategy: The Blurry Line Between Strategy Formulation and Strategy Implementation," British Journal of Management, Vol. 26 No. 5, pp. S17-S21.

Levina, N. and Vaast E. (2005). The Emergence of Boundary Spanning Competence in Practice: Implications for Implementation and Use of Information Systems," MIS Quarterly, Vol. 29 No. 2, pp. 335-363.

López-Bayón, S., and López-Fernández B. (2016). "Partner Empowerment and Relationship Failure in Franchising," Journal of Small Business Management, Vol. 54 No. 4, pp. 10591079. 
López-Fernández, B. and López-Bayón, S. (2018), “Antecedents of Early Terminations in Franchising: Franchisor versus Franchisee Cancelations”, Small Business Economics, Vol. 50 No. 4, pp. 667-695

Lundqvist, M., Middleton, K.W. and Nowell, P. (2015). "Entrepreneurial identity and role expectations in nascent entrepreneurship," Industry and Higher Education, Vol. 29 No. 5, pp. 327-344.

Jang, S. and Park, K. (2019), “A Sustainable Franchisor-Franchisee relationship Model: Toward the Franchise Win-Win Theory", International Journal of Hospitality Management, Vol. 76 No. 6, pp. 13-24.

Madanoglu, M. and Castrogiovanni, G.J. (2018), "Franchising Proportion and Network Failure", Small Business Economics, Vol. 50 No. 4, pp. 697-715.

Marshall, B., Cardon, P., Poddar, A. and Fontenot, R. (2013), "Does Sample Size Matter in Qualitative Research?: A Review of Qualitative Interviews in IS Research", Journal of Computer Information Systems, Vol. 54 No. 1, pp. 11-22.

Merrilees, B. and L. Frazer (2013). "Internal Branding: Franchisor Leadership as a Critical Determinant," Journal of Business Research, Vol. 66 No. 2, pp. 158-164.

Mills, C.E. (2011). "Enterprise Orientations: A Framework for Making Sense of Fashion Sector Start-up," International Journal of Entrepreneurial Behavior and Research, Vol. 17 No. 3, pp. $245-271$.

Mills, C.E., and Pawson, K. (2006). "Enterprising Talk: A Case of Self Construction," International Journal of Entrepreneurial Behavior and Research, Vol. 12, No. 6, pp. $328-344$.

Mills, C.E., and Pawson, K. (2012). "Integrating Motivation, Risk-Taking, and Self-identity: A Typology of ICT Enterprise Development Narratives, ” International Small Business Journal, Vol. 30 No. 5, pp. 584-606. 
Nicolson, H. and Carroll, B. (2013). "Identity Undoing and Power Relations in Leadership Development," Human Relations, Vol. 66 No. 4, pp. 1225-1248.

Nijmeijer, K.J., Fabbricotti, I.N. and Huijsman, R. (2014). "Making Franchising Work: A Framework Based on a Systematic Review," International Journal of Management Review, Vol. 16 No 1, pp. 62-83.

O'Connor, E. (2002). "Storied Business: Typology, Intertextuality and Traffic in Entrepreneurial narrative,” Journal of Business Communication, Vol. 39 No. 1, pp. 3654.

Orlikowski, W. J. (1996). “Improvising Organizational Transformation Over Time: A Situated Change Perspective," Information Systems Research, Vol. 7 No. 1, pp. 63-92.

Orlikowski, W. J. (2006). "Material Knowing: The Scaffolding of Human Knowledgeability," European Journal of Information Systems, Vol. 15 No. 5, pp. 460-466.

Orlikowski, W. J. (2007). "Sociomaterial Practices: Exploring Technology at Work," Organization Studies, Vol. 28 No. 9, pp. 1435-1448.

Oswick, C. and Robertson, M. (2009). "Boundary Objects Reconsidered: From Bridges and Anchors to Barricades and Mazes," Journal of Change Management, Vol. 9 No. 2, pp. 179-193.

Pardo-del-Val, M., Martínez-Fuentes, C., López-Sánchez, J. and Minguela-Rata, B. (2014). "Franchising: The Dilemma Between Standardization and Flexibility," The Services Industries Journal, Vol. 34 No. 9/10, pp. 828-842.

Rae, D. (2004). "Entrepreneurial Learning: A Practical Model from the Creative Industries," Education + Training, Vol 46 No. 8/9, pp. 492-500.

Reissner, S.C. (2005). "Learning and innovation: A narrative analysis," Journal of Organizational Change Management, Vol. 18 No. 5, pp. 482-495. 
Shane, S.A. and Spell, C. (1998). "Factors for New Franchise Success," Sloan Management Review, Vol. 39, Spring, pp. 43-50.

Soin, K. and Scheytt T. (2006). "Making the Case for Narrative Methods in Cross-Cultural Organizational Research,” Organizational Research Methods, Vol. 9 No. 1, pp. 55-77.

Solis-Rodriguez, V. and Gonzalez-Diaz M. (2012). "How to Design Franchise Contracts: The Role of Contractual Hazards and Experience," Journal of Small Business Management, Vol. 50 No. 4, pp. $652-677$

Spee, A.P. and Jarzabkowski, P. (2009). "Strategy Tools as Boundary Objects," Strategic Organization, Vol. 7 No. 2, pp. 223-232.

Stanworth, J. and Kirby, D. (1993). "Franchising and Franchising Entrepreneurship: Socioeconomic Considerations in Development," in Research at the Marketing/Entrepreneurship Interface, Hills, G., Laforge, R. and Muzyka D. (Eds), University of Illinois, Chicago.

Stanworth, J., Purdy, D., English W. and Willems, J. (2001). "Unravelling the Evidence on Franchise System Survivability," Enterprise and Innovation Management Studies, Vol. 2 No. 1, pp. 49-64.

Stanworth, C., Purdy, D., Stanworth, J., Watson, A. and Healeas, S. (2004). "Franchising as a Small Business Growth Strategy: A Resource-Based View of Organizational Development," International Small Business Journal, Vol. 22 No. 6, pp. 539-559.

Star, S.L. and Griesemer, J.R. (1989). “Institutional Ecology, 'Translations', and Boundary Objects: Amateurs and Professionals in Berkeley's Museum of Vertebrate Zoology 1907-39," Social Studies of Science, Vol. 19 No. 1, pp. 387-420.

Swartz, L. N. (2001). "Franchising Successfully Circles the Globe," in D.H.B. Welsh and I. Alon (Eds.), International Franchising in Emerging Markets: Central and Eastern Europe and Latin America (pp. 43-61). Chicago: CCH, Inc. 
Tracy, S.J. (2013). Qualitative Research Methods: Collecting Evidence, Crafting Analysis, Communicating Impact, John Wiley and Sons, New York.

Tsoukas, H. and Chia, R. (2002). “On Organizational Becoming: Rethinking Organizational Change,” Organization Science, Vol. 13 No. 5, pp. 567-582.

Wadsworth, F. H., and Cox, K.C. (2011). “Identifying Risky Franchises,” Journal of Marketing Channels, Vol. 18 No. 1, pp. 43-55.

Watson, A. (2008). Small Business Growth Through Franchising: A Qualitative Investigation," Journal of Marketing Channels, Vol. 15 No. 1, pp. 3-21.

Watson A. and Johnson R. (2010). "Managing the Franchisor-Franchisee Relationship: A Relationship Marketing Perspective,” Journal of Marketing Channels, Vol. 17 No. 1, pp. $51-68$.

Watson, A., Stanworth, J. Healeas, S., Purdy, D. and Stanworth, C. (2005). “Retail Franchising: An Intellectual Capital Perspective," Journal of Retailing and Consumer Services, Vol. 12 No. 1, pp. 25-34.

Watson, T.J. (2008). "Managing Identity: Identity Work, Personal Predicaments, and Structural Circumstances", Organization, Vol. 15 No. 6, pp. 121-143.

Watson, T.J. (2009). "Entrepreneurial Action, Identity Work and the Use of Multiple Discursive Resources," International Small Business Journal, Vol. 27 No 3, pp. 251-274.

Welsh, D.H.B., Alon, I. and Falbe, C.M. (2006). “An Examination of International Retail Franchising in Emerging Markets”, Journal of Small Business Management, Vol. 44 No. 1, pp. $130-14$

Weick, K.E. and Quinn R.E. (1999). “Organizational Change and Development,” Annual Review of Psychology, Vol. 50 No. 1, pp. 361-386. 
Whittle, A. and Suhomlinova, O. (2010). "Funnel of Interests: The Discursive Translation of Organizational Change,” The Journal of Applied Behavioral Science, Vol. 46 No. 1, pp. 16-37.

Wright, O. and McAuley, A. (2012). “Australian franchising research: Review, synthesis and future research directions", Australasian Marketing Journal, Vol. 20 No. 2, pp 158-163. 